\title{
Study on the Relationship between Financial Development and Poverty Alleviation in Guizhou Province Based on Kuznets Curve
}

\author{
Jianchun Yang \\ School of Business Administration, Guizhou University of Finance \& Economics, Guiyang 550025 \\ Huaxi Zone, Guiyang, China \\ E-mail:772957289@qq.com \\ Chaochao Liang \\ School of Business Administration, Guizhou University of Finance \& Economics, Guiyang 550025 \\ Huaxi Zone, Guiyang, China \\ E-mail:416216094@qq.com
}

Received May 1, 2018

Accepted August 19, 2018

\begin{abstract}
Based on the construction of the nonlinear effect model of financial poverty alleviation, the paper used Granger causality test and regression analysis to analyze the relationship between financial development and poverty alleviation in Guizhou province. The results present that the relationship between financial development and poverty alleviation follows the Kuznets inverted U-curve, which means that financial development, may have positive effects on poverty alleviation in the early stage and then have negative effects on poverty alleviation in later stage. Based on this, in-depth analysis was conducted and development suggestions were put forward.
\end{abstract}

Keywords: kuznets curve, financial development, poverty reduction

\section{Introduction}

Guizhou is the province with the largest number of poor people, the widest area of poverty and the highest intensity of poverty in China. Since the reform and opening up, Guizhou province has made significant progress in poverty alleviation. The number of poor people in Guizhou has decreased from 15.87 million in 1978 to 2.36 million in 2007. The number of poor people in Guizhou province has shrunk from 6.26 million in 2008 to 4210,000 in 2010 measured by the low-income line rather than the absolute poverty line which was no longer be officially adopted in the measurement of poverty since 2008. The number of poor people in Guizhou province has decreased from
11.49 million in 2011 to 4.93 million in 2015 since the country have adopted the poverty line of 2,300 yuan per person in 2011. And the poverty rate of Guizhou has reduced from $59.1 \%$ in 1978 to $6.5 \%$ in 2007 . According to the low-income line, which was officially adopted to replace the absolute poverty line to measure the poverty in 2008 , poverty rate of Guizhou province has decreased from $17.4 \%$ in 2008 to $12.1 \%$ in 2010 ; The poverty rate in Guizhou province has decreased from $33.1 \%$ in 2011 to $14.03 \%$ in 2015 based on the poverty line of 2,300 yuan per person adopted since 2011. However, Guizhou province is still the main battlefield of poverty alleviation. Under the new situation, precise poverty alleviation of Guizhou province still faces many bottlenecks and constraints, including the backward economic development, the 
fragile ecological environment, low quality of the population, the lag of public service, especially the financing constraint problem. Therefore, it is of great practical significance to study the relationship between financial development and poverty alleviation in Guizhou province.

\section{Literature Review}

For a long time, domestic and foreign scholars have done a lot of research on the relationship between financial development and poverty but achieved no agreement on that due to the inconsistent result on analysis of the model, the index selection, measurement error, the heterogeneity of the data, and the related explanation variable. After making systematic review of existing research, we have found three main ideas in terms of the relationship between financial development and poverty. The first thinking is that financial development is positively correlated with poverty alleviation. Through conducting analysis, Jalilian \& Kirkpatrick (2002), Akhter et al (2010) found a positive correlation between financial development and poverty alleviation and believed that financial development was beneficial to poverty alleviation. The second view is that financial development is not positively correlated with poverty alleviation. Fowowe \& Abidoye (2013) believed that financial development poverty may not help to reduce the poverty. By conducting dynamic panel data analysis, Seven \& Coskun (2016) explored whether the development of Banks and stock markets was helpful to alleviate income inequality and poverty in emerging countries. The research results showed that though the financial development promoted economic growth, but it did not serve poor people in emerging countries, both banks and the stock market did not play an important role in poverty reduction. The third view hold is that there is a nonlinear relationship between financial development and poverty alleviation. Greenwood \& Jovanovic (2009) suggested that the relationship between financial development and income distribution was based on the Kuznets "inverted U" curve, so financial development might have indirect impact on the poverty reduction by influencing income distribution directly, which meant that the relationship between financial development and poverty alleviation may be demonstrated by using Kuznets "inverted U" curve. Cui yanjuan (2014) selected financial development scale and financial efficiency as the index of financial development and adopted panel data to examine the impact of financial development on poverty reduction, verifying the prediction of Greenwood \& Jovanovic.

The diversification of the research result on the relationship between financial development and poverty alleviation reports that there is room for further study about the topic. From the perspective of research content, there are many researches on the causal relationship between financial development and poverty alleviation but less discussion on the mechanism of the impact of financial development on poverty alleviation; From the perspective of research methods, most researches are carried out under the framework of linear model, and limited ones study the non-linear relationship. In terms of the research object, the research on regional financial poverty alleviation is very limited while the object of many studies in the financial poverty alleviation always is the country. Therefore, this paper will probe into the non-linear relationship between financial development and poverty alleviation in Guizhou province.

\section{Model Construction and Variable Description}

\subsection{Model Building}

To examine the non-linear effect between financial development and poverty alleviation, this paper constructs the following analysis model.

$$
\begin{gathered}
\operatorname{pov}_{t}=\alpha_{0}+\beta_{1} \cdot \operatorname{fin}_{t}+\beta_{2} \cdot \operatorname{fin}_{t}^{2}+\varepsilon_{t} \\
\operatorname{pov}_{t}=\alpha_{0}+\beta_{1} \cdot \operatorname{fin}_{t}+\beta_{2} \cdot \mathrm{fin}_{t}^{2}+\beta_{3} \cdot \ln r j g d p_{t}+\beta_{4} \cdot c r+\varepsilon_{t}
\end{gathered}
$$

Model (1) examines the direct non-linear effect of financial development on poverty alleviation which is mainly determined by poor people's access and accessibility of financial product services. Model (2) examines the indirect non-linear effect of financial development on poverty alleviation. Indirect effect of financial development on poverty alleviation means that the financial development may influence poverty alleviation through promoting economic growth or income distribution which is beneficial to alleviating poverty. pov, rjgdp and crPov respectively represent 
poverty alleviation, economic growth, income distribution. fin is used to represent variable of financial development which is measured from two perspectives including financial development scale (fir) and the financial development efficiency $(f e) . \varepsilon$ refers to the error term; $\alpha$ and $\beta$ are the estimated coefficients; $\mathrm{t}$ represents the time of period. If $\beta_{1}>0$ and $\beta_{2}<0$ are workable at the same time, the relationship between financial development and poverty alleviation follows inverted $\mathrm{U}$ - shape. If $\beta_{1}<0$ and $\beta_{2}>0$ are established at the same time, U-shape relationship between financial development and poverty alleviation is reported exist. If $\beta_{2}=0$, linear relationship between financial development and poverty alleviation is demonstrated.

\subsection{Variable Declaration}

- Poverty alleviation (pov). Indexes which were used to measure poverty mainly include poverty rate and poverty index, sen index, FGT index, etc. Considering the availability of data as well as the long research time span, this paper adopts the Engel coefficient of rural households as indexes measuring poverty level. The lower the Engel coefficient of rural households is, the higher the degree of poverty alleviation is, and vice versa.

- Financial development (fin). This paper measured the financial development from two perspectives including the financial development efficiency $(f e)$ and the financial development scale (fir). The ratio of loan/savings deposit is adopted to measure the efficiency of financial development $(f e)$. We organized the data of the deposit and loan of financial institutions and the GDP of the region then compiled them into financial related rate to measure the scale of financial development.

- Economic growth (RJGDP). This paper selected per capita GDP to measure the economic development of Guizhou province. In order to reduce the influence caused by unusually large fluctuation of variable data and possible heteroscedasticity, we conducted a logarithm of this index.

- Income distribution ( $c r$ ). In terms of income distribution, existing research always adopted Theil index, Gini coefficient and per capita income rate of urban and rural residents to measure it. In this paper, the urban-rural gap was measured by the per capita disposable income of urban residents and the per capita net income of rural residents.

\section{Econometric Analysis}

This paper used Eviews software to carry out econometric analysis. The data used in this paper was from Guizhou statistical yearbook, and the data sampling period is from 1978 to 2016.

\subsection{Stationarity Test.}

We adopted augmented unit root (ADF), which was proposed by Dickey and Fuller, to examine the stationarity of time series data. The unit root test results were demonstrated in Table 1(see Table 1) and they presented that pov, fir, fe, RJGDP, $\mathrm{cr}$ under the first order difference were passed the significance level of $1 \%$ ADF unit root test, reporting that first order difference sequence of every variable was stationary series.

Table 1 Variable Unit Root Test Results

\begin{tabular}{|c|c|c|c|c|c|c|}
\hline \multirow{2}{*}{ variable } & \multirow{2}{*}{$\begin{array}{c}\text { Test type }(\mathrm{C}, \\
\mathrm{T}, \mathrm{L})\end{array}$} & \multirow{2}{*}{$\begin{array}{c}\text { ADF } \\
\text { Test value }\end{array}$} & \multicolumn{3}{|c|}{ Critical values at each level of significance } & \multirow{2}{*}{$\begin{array}{l}\text { The inspection } \\
\text { results }\end{array}$} \\
\hline & & & $1 \%$ & $5 \%$ & $10 \%$ & \\
\hline Dpov & $(\mathrm{C}, \mathrm{T}, 0)$ & -6.0926 & -4.2268 & -3.5366 & -3.2003 & smooth \\
\hline Dfir & $(\mathrm{C}, \mathrm{T}, 3)$ & -4.3777 & -4.2529 & -3.5486 & -3.2070 & smooth \\
\hline$D f e$ & $(\mathrm{C}, \mathrm{T}, 0)$ & -6.1837 & -4.2268 & -3.5366 & -3.2003 & smooth \\
\hline Drjgdp & $(\mathrm{C}, 0,0)$ & -3.7146 & -3.6210 & -2.9434 & -2.6103 & smooth \\
\hline$D c r$ & $(\mathrm{C}, \mathrm{T}, 0)$ & -4.5656 & -4.2268 & -3.5366 & -3.2003 & smooth \\
\hline
\end{tabular}

Note: C: includes intercept term; T: includes trend term; L: lag order number; D plus variable represents the first difference. 


\subsection{Granger Causality Test}

Granger causality test results (see table 2) demonstrated that Guizhou financial development scale, financial development efficiency and economic growth was the Granger cause of poverty alleviation, and there was two-way Granger causality between financial development scale and economic growth. It revealed that the financial development of Guizhou had not only the direct promotion effect on poverty alleviation, but also had the indirect promotion effect on poverty alleviation by promoting economic growth and reducing poverty. At the same time, the results showed that there was no Granger causality of statistical significance between income distribution and poverty alleviation, reporting that at present stage in Guizhou, the indirect promoting effects of financial development on poverty alleviation by improving income distribution was not obvious.

Table 2 Granger Causality Test Results

\begin{tabular}{|c|c|c|c|}
\hline Lag order & Null hypothesis & F statistic & $P$ values \\
\hline \multirow{2}{*}{ Lags:2 } & fir does not Granger Cause pov & 3.3025 & 0.0497 \\
\hline & pov does not Granger Cause fir & 0.3827 & 0.6854 \\
\hline \multirow{2}{*}{ Lags: 2} & $f e$ does not Granger Cause pov & 3.5692 & 0.0400 \\
\hline & pov does not Granger Cause $f e$ & 0.5469 & 0.5841 \\
\hline \multirow{2}{*}{ Lags: 1} & Lnjgdp does not Granger Cause pov & 4.3345 & 0.0447 \\
\hline & pov does not Granger Cause Lnjgdp & 2.0377 & 0.1623 \\
\hline \multirow{2}{*}{ Lags: 1} & $c r$ does not Granger Cause pov & 1.1291 & 0.3359 \\
\hline & pov does not Granger Cause $c r$ & 0.4217 & 0.6595 \\
\hline \multirow{2}{*}{ Lags: 2} & fir does not Granger Cause Lnjgdp & 2.6948 & 0.0829 \\
\hline & Lnjgdp does not Granger Cause fir & 7.3300 & 0.0024 \\
\hline
\end{tabular}

\subsection{Regression Analysis}

According to the model (1) and model (2), we conducted regression analysis by involving indexes including financial development efficiency $(f e)$ and financial development scale (fir) to measure the level of financial development and test the non-linear effect of financial development on poverty reduction in Guizhou province. Regression results were reported in Table 3.

Regression analysis results showed that in the regression model (1) to (4), the respective coefficients of financial development scale (fir) and the financial development efficiency $(f e)$ are $\beta_{1}>0, \beta_{2}<0$, which presented that regardless of from perspective of direct or indirect promoting effects, the reversed U-shape relation between financial development and poverty alleviation in Guizhou has been found, verifying Greenwood \& Jovanovic's point of view.

Based on the regression model (1) and regression model (2), Matlab software was used to draw figures describing the non-liner relationship between financial development scale (fir) and poor reduction and the one of financial development efficiency $(f e)$ and poor reduction (pov). From figure 1 and figure 2, we can see more clearly that financial development may have positive effects on poverty alleviation in the early stage and then have negative effects on poverty alleviation later. 
Table 3 The Effects of Guizhou Financial Development on Poverty Alleviation: Regression Analysis (Explained Variable: pov)

\begin{tabular}{|c|c|c|c|c|}
\hline \multicolumn{5}{|c|}{ variable: pov) } \\
\hline variable & The regression model (1) & The regression model (2) & The regression model ( 3 ) & The regression model (4) \\
\hline constant & $\begin{array}{l}0.6413^{* * *} \\
(2.8249)\end{array}$ & $\begin{array}{l}-1.4503^{* * * *} \\
(-7.8414)\end{array}$ & $\begin{array}{c}0.7674^{* * * *} \\
(10.4536)\end{array}$ & $\begin{array}{l}-1.0104^{* * *} \\
(-3.3117)\end{array}$ \\
\hline Fir & $\begin{array}{c}0.1172^{* * * *} \\
(17.8113)\end{array}$ & & $\begin{array}{l}0.2755^{* * *} \\
(2.7737)\end{array}$ & \\
\hline$f i r^{2}$ & $\begin{array}{l}-0.0608^{* * *} \\
(-5.7782)\end{array}$ & & $\begin{array}{l}-0.0809^{* * *} \\
(-4.1021)\end{array}$ & \\
\hline $\mathrm{Fe}$ & & $\begin{array}{l}3.6469^{* * * *} \\
(9.8761)\end{array}$ & & $\begin{array}{l}2.9913^{* * * *} \\
(6.1417)\end{array}$ \\
\hline$f e^{2}$ & & $\begin{array}{l}-1.5379^{* * * *} \\
(-8.5945)\end{array}$ & & $\begin{array}{l}-1.2588^{* * * *} \\
(-5.7284)\end{array}$ \\
\hline Lnrjgdp & & & $\begin{array}{l}-0.0344^{* *} \\
(-2.0620)\end{array}$ & $\begin{array}{l}-0.0219^{* *} \\
(-2.4372)\end{array}$ \\
\hline $\mathrm{Cr}$ & & & $\begin{array}{l}-0.0223 \\
(-1.0093)\end{array}$ & $\begin{array}{l}0.0282^{* * *} \\
(2.8676)\end{array}$ \\
\hline$R^{2}$ & 0.8896 & 0.9153 & 0.9039 & 0.9329 \\
\hline
\end{tabular}

Note: $\mathbf{R}^{2}=$ goodness of fit; $* * * \mathbf{p}<.01$ and $* * \mathbf{p}<.05$; and the $\mathbf{t}$-statistic of the estimated values of each parameter was presented in the bracket.

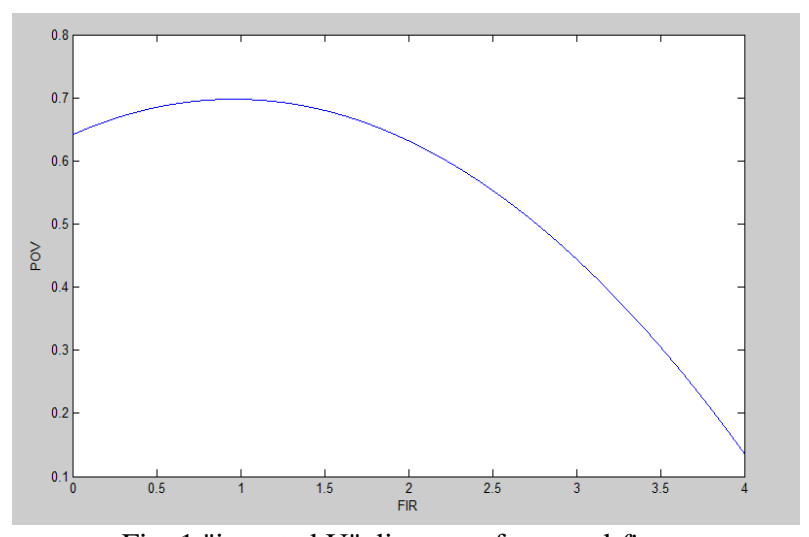

Fig. 1 "inverted U" diagram of pov and fir

\section{Conclusions and Discussions}

\subsection{Conclusions}

The following conclusions can be obtained through metering analysis:

(1) The non-linear relationship between the financial development and poverty alleviation in Guizhou province follows the Kuznets' inverted u-shaped curve. Due to the low level of economic development, high poverty level and high poverty rate, Guizhou province has been in the "poverty trap". Thus, in the early stage

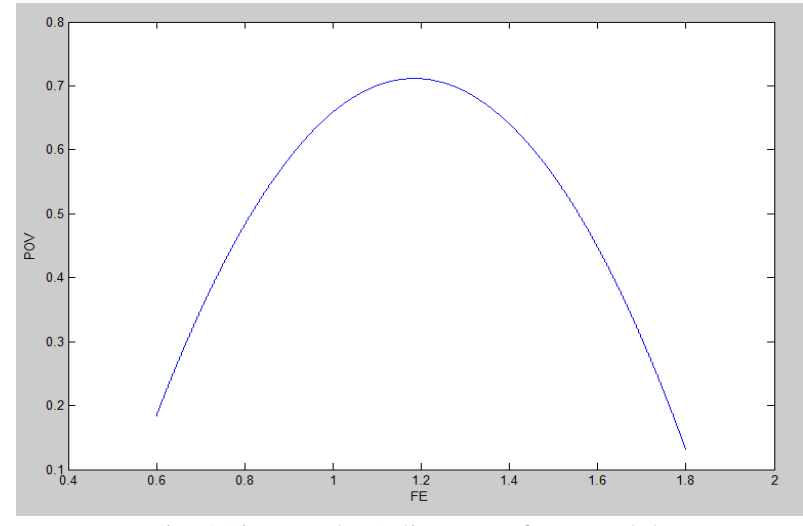

Fig. 2 "inverted U" diagram of pov and fe

of economic development, it is difficult for poor people to make benefit from financial development since they are limited by the high threshold of financial services. With the development of finance and economy in Guizhou province, the threshold of financial services has been gradually lower, thus the financial development may gradually be conducive to the alleviation of poverty.

(2) At present, the financial development of Guizhou province plays an active role in promoting poverty alleviation. As the core of modern economy, finance plays an important role in capital formation. 
Finance acts as a mediator which can promote the transformation of savings to investment and increase the capital accumulation, thus prompting economy out of the "poverty trap" and reaching a higher level of equilibrium.

\subsection{Theoretical Contributions}

Based on the related index and data of financial development, poverty alleviation, economic growth and income distribution in Guizhou province, this paper verified the direct and indirect non-linear relationship between financial development and poverty alleviation which follow the Kuznets' inverted u-shaped curve.

\subsection{Suggestions}

To sum up, on the one hand, Guizhou province should expand the financing scale for poverty-stricken areas and poor groups in the financial poverty alleviation work. In the development of modern economy and society, capital is a middle stage and one of key factors. For poverty-stricken areas, the need for fund is even more urgent. Therefore, it is necessary to increase loans for poor areas and poor groups, encourage and guide various financial institutions to expand the agricultural loans amount in poverty-stricken areas, and promote the reduction of social financing costs. On the other hand, the degree of precision of financial poverty alleviation may be strengthening. The fund for poverty alleviation may be uniformly arranged and government should make target investment according to the cause and the type of poverty. Government may concentrate to promoting infrastructure construction, investment for basic education and economic restructuring.

\section{Acknowledgements}

The project is supported by The Ministry of Education Research in the Humanities and Social Sciences Planning Fund (No. 16YJAZH069).

\section{References}

Chengwei Huang, Tao Ye. Provincial model of poverty alleviation: a study on the precise poverty alleviation model of Guizhou's precise poverty alleviation[M]. Beijing: socialscience literature press, 2016.

Akhter S, Liu Y, Daly k. Cross Country Evidence on the Linkages between Financial Development and Poverty[J]. International Journal of Business and Management, 2009,5(11):207-214

Jalilian H, Kirkpatrick. Growth and Poverty Reduction in Developing Countries[J]. International Journal of Finance and Economics, 2002,7(2):97-108.

Fowowe B, Abidoye B. The effect of financial development on poverty and inequality in African countries[J]. Manchester School, 2013,81(4):562-585.

Seven U, Coskun Y. Does financial development reduce income inequality and poverty? Evidence from emerging countries[J]. Emerging Markets Review, 2016,26:34-63.

Jeremy Greenwood, Boyan Jovanovic. Financial Development, Growth, and Distribution of Income[J]. Journal of Political Economy, 1990,98(5):1076-1107.

Yanjuan Cui. Financial development and poverty alleviation: path, effect and policy implications[M]. Beijing: economic science press, 2014.

Jianchun Yang, Rui Shi. Comparison of dynamic effects of financial support for tourism industry development -- taking guizhou and zhejiang provinces as examples[J]. Social scientists, 2014,(6):88-92.

Rongrong Shi et al. The threshold effect of financial poverty reduction and its empirical test -- based on the research on the data of China's western provinces[J]. China soft science, 2013,(3):32-41. 